\title{
Parliamentary Threshold in Integrative Legal Perspective: Indonesian Case
}

\author{
Sholahuddin Al-Fatih \\ Faculty of Law, University of Muhammadiyah Malang, Malang, \\ East Java, Indonesia \\ sholahuddin.alfath@gmail.com
}

\begin{abstract}
The article aims at discussing the application of parliamentary threshold legal norms in an integrative legal perspective. Through historical, conceptual and statutory approaches, this study tries to examine holistically and prescriptively the dynamics of applying parliamentary thresholds in legislative elections. This article makes the thinking of leaders on integrative law a benchmark and an analytical knife. The results of this study demostrates that the application of parliamentary thresholds in elections based on an integrative legal perspective is not appropriate because it has not been able to guarantee the fulfillment of a sense of justice for all Indonesians because integrative law views a legal event as a comprehensive state of pros and cons. This research is expected to help academics and legal practitioners, especially with regard to election law to be able to dig out deeper into integrative law, not only from one or two experts, but from several other experts.
\end{abstract}

Keywords: Parliamentary Threshold; Elections; Integrative; Legal Perspective

\section{A. Introduction}

Threshold or rather the electoral threshold when it was first introduced in the General Election, refers to the provisions in Article 39 
paragraph (3) of Law No. 3 of 1999 concerning Elections. ${ }^{1}$ At that time, the electoral threshold was defined as the minimum threshold for the party to participate in elections in the next period. ${ }^{2}$ Before the 2004 elections were held, the provisions on the threshold were stipulated in Article 143 paragraph (1) of Law No. 12 of 2003 concerning the Elections of Members of the House of Representatives, the Regional Representative Council, and the Regional House of Representatives. ${ }^{3}$ Since then, almost every election period, rules on thresholds are imposed and are always revised with changes in terms or numbers. ${ }^{4}$

The threshold used in the 2004 election regime was also adopted in the 2009 election. In the special committee (Panitia Khusus/ Pansus) of the Electoral Law, the government and legislative institutions agreed to change the term electoral threshold used in previous elections to a parliamentary threshold. The parliamentary threshold regulation for the 2009 elections is mentioned in Law No. 10 of 2008 concerning The Election of Members of the House of Representatives, The House of Representatives, and the Regional House of Representatives. Meanwhile, in the run-up to the 2014 elections, the regulation of the parliamentary threshold was stipulated in Law No. 8 of 2012 concerning the Elections of Members of the House of Representatives, the Regional Representative Council, and the Regional

1 Sholahuddin Al-fatih, "Economic Analysis Relationship in Determining The Size of Parliamentary Threshold in Indonesia," Indonesian Journal of Law and Policy Studies 1, no. 2 (2020): 152-58, https: / / doi.org/10.31000/ijlp. v1i2.3176.g1988.

2 Sholahuddin Al-Fatih, "Parliamentary Threshold in Perspective of General Statement and Modern Law," Jurnal Hukum Replik 8, no. 2 (2020): 172-83, https: / / doi.org/10.31000/jhr.v8i2.3582.g2000.

3 Sholahuddin Al-Fatih, "Akibat Hukum Regulasi Tentang Threshold DalamPemilihan Umum Legislatif Dan Pemilihan Presiden: Kajian Putusan Mahkamah Konstitusi Nomor 52/PUU-X/2012 Dan Nomor 14/PUUXI/2013,”Jurnal Yudisial 12, no. 1 (2019): 17-38, https: / / doi.org/10.29123 / jy.v12i1.258.

4 Sholahuddin Al Fatih, "Implementasi Parliamentary Threshold Dalam Pemilihan Anggota Dprd Provinsi Dan Dprd Kabupaten/Kota," Ahkam: Jurnal Hukum Islam 6, no. 2 (2018), https: / / doi.org/10.21274 / ahkam.2018.6.2.363388. 
House of Representatives. In the 2019 concurrent elections, the regulation of the parliamentary threshold is stipulated in Law No. 7 of 2017 concerning Elections. ${ }^{5}$

The implementation of the electoral threshold as well as the parliamentary threshold raises pros and cons among the public, ${ }^{6}$ resulting in the application of norm reviewing of the electoral threshold as well as the parliamentary threshold to the Constitutional Court. The reason for the review is more based on the protection of human rights, especially the civil and political rights of citizens who are systemically considered to be castrated by the enactment of threshold mechanisms, because many voter votes will be wasted through that mechanism. ${ }^{7}$ Nevertheless, until the 2019 concurrent elections, the legal norms of the parliamentary threshold remain in place.

Based on that background, the author tries to analyze the application of parliamentary thresholds in elections in Indonesia in an integrative legal perspective. The author hopes to see the history of the implementation of the parliamentary threshold in the election, to dig into the facts and data related to the pros and cons of the application of the parliamentary threshold. Through this study, the author hopes to find a link between parliamentary thresholds, elections and integrative law, laws that are not viewed as myopic. This article is expected to contribute in the field of law, especially in the field of electoral law, constitutional law and the study of human rights which may be able to provide findings for advancement in the field of legal science and assist academics and practitioners in implementing parliamentary thresholds in the future.

Originally a research, this article applies conceptual approach

5 Sholahuddin Al-fatih, "Electoral Regulation in Indonesia: Is It Modern Law?,” Unnes Law Journal 6, no. 2 (2020): 205-16, https: / / doi.org/ https: / / doi.org/10.15294/ulj.v6i2.41627.

6 Sholahuddin Al Fatih, "Penerapan Threshold dalam Pemilu," Audito Comparative Law Journal 1, no. 2 (2020): 78-84, https:// doi.org/https:// doi. org/10.22219/audito.v1i2.13973.

7 Al-Fatih, "Akibat Hukum Regulasi Tentang Threshold DalamPemilihan Umum Legislatif Dan Pemilihan Presiden: Kajian Putusan Mahkamah Konstitusi Nomor 52/PUU-X/2012 Dan Nomor 14/PUU-XI/2013.” 
and statutory approach. ${ }^{8}$ Legal research is a study that examines norms, ${ }^{9}$ relating to overlap, absence and vagueness in existing norms. The norms that are being reviewed in this study are related to the parliamentary threshold norm. The concept used as a measuring instrument is the concept of integrative law, while the legislation used in this study is the Law on Legislative Elections. Through prescriptive analysis, ${ }^{10}$ the authors try to find new arguments relating to parliamentary thresholds in an integrative legal perspective.

\section{B. Result and Discussion}

The threshold according to Arend Lipjhart is the minimum vote obtained by an election participant's political party in order to gain a seat at the district level or the minimum percentage that an election participant's political party must obtain from the total national voter turnout. ${ }^{11}$ Meanwhile, August Mellaz defines the threshold as a threshold that must be exceeded by a political party, in order to be able to send its representatives to a representative institution. ${ }^{12}$ Thresholds, electoral thresholds, or parliamentary thresholds are usually expressed with a percentage of valid voting or in some countries can be expressed in the form of minimum seats, where the term is commonly used in the context of elections. ${ }^{13}$

8 Peter Mahmud Marzuki, Penelitian Hukum (Jakarta: Kencana Prenada Media Group, 2014).

9 Irwansyah, Penelitian Hukum: Pilihan Metode \& Praktik Penulisan Artikel, ed. Ahsan Yunus (Yogyakarta: Mirra Buana Media, 2020).

10 Peter Mahmud Marzuki, Penelitian Hukum: Edisi Revisi, Cetakan ke (Jakarta: Kencana, 2017), https://books.google.co.id/books?id=CKZADwAAQ BAJ\&printsec $=$ frontcover $\& \mathrm{dq}=$ Marzuki, + Peter + Mahmud $,+(2014),+$ Pen elitian+Hukum,+Cetakan+ke-9,+Jakarta:+Kencana+Media+Group.\&hl $=\mathrm{id} \&$ sa $=$ X\&ved $=0$ ahUKEwiNlIjqlbTpAhXWWisKHWktCXAQ6AEIMjA $\mathrm{B} \# \mathrm{v}=$ onepage $\& \mathrm{q} \& \mathrm{f}=$ false.

11 Arend Lijphart, Patterns of Democracy, Government Forms \& Performance in Thirty-Six Countries, 2nd ed. (Yale: Yale University Press, 2012).

12 August Mellaz, "Praktek Penerapan Keberlakuan 3,5 Persen Ambang Batas Parlemen Secara Nasional Undang-Undang Nomor 8 Tahun 2012 Tentang Pemilu” (Jakarta, 2012), http://www.spd-indonesia.com/wp-content/ uploads / 2016/04/ Ambang-Batas-Tanpa-Batas.pdf.

13 Al-Fatih, "Akibat Hukum Regulasi Tentang Threshold DalamPemilihan 
The threshold concept was originally used to look at the level of competition of political parties in contesting seats in constituencies in a proportional electoral system. The concept connects the size of the constituency (district magnitude) with the formula of obtaining party seats with the quota method. ${ }^{14}$ In Indonesia, the application of threshold, electoral threshold, or parliamentary threshold becomes a new norm in the implementation of elections and almost certainly always changes in the size of each election period. Table 1 draws the application of electoral threshold or parliamentary threshold regulations in electoral law.

It is demostrated from the Table 1 that there are 5 electoral laws that specifically govern the electoral threshold or parliamentary threshold. The change in the size of the parliamentary threshold, from the start it was set at $2.5 \%$ to $4 \%$ in the 2019 election (the last election that was held by the government), caused quite a lot of voter votes to be wasted. This condition, factually deprives citizens of the constitutional rights, because the legitimacy of their choice in the election, is wasted because of the parliamentary threshold policy.

As happened in the last election in 2019, the results were obtained 7 political parties participating in the 2019 election failed to qualify for parliament because they could not pass the parliamentary threshold. Perindo (Persatuan Indonesia Party, founded by Hary Tanoe Soedibjo), Berkarya (Berkarya Party, founded by Tommy Soeharto), PSI (Indonesia Solidarity Party, founded by Grace Natalie), Hanura (Hati Nurani Rakyat Party, founded by Wiranto), PBB (Bulan Bintang Party, being famous by Yuzril Ihza Mahendra), Garuda (Gerakan Perubahan Indonesia Party, founded by Harmoko) and PKPI (Keadilan dan Persatuan Indonesia Party, founded by Tri Soetrisno) that failed to cross the parliamentary threshold (with a total of $13,595,842$ votes)..$^{15}$ This means that of $13,595,842$ public votes are

Umum Legislatif Dan Pemilihan Presiden: Kajian Putusan Mahkamah Konstitusi Nomor 52/PUU-X/2012 Dan Nomor 14/PUU-XI/2013.”

14 Al-Fatih.

15 Titi Anggraini, "Ambang Batas Parlemen Tinggi 7\% Dinilai Berdampak Banyak Suara Sah Terbuang,” Detik News, 2020. 
Table 1. Regulation of the Electoral Threshold-Parliamentary Threshold in elections

\begin{tabular}{|c|c|c|}
\hline No & $\begin{array}{c}\text { Electoral } \\
\text { Regulation }\end{array}$ & About \\
\hline 1. & $\begin{array}{l}\text { Article } 39 \\
\text { paragraph (3) } \\
\text { of Law No. } 3 \\
\text { of } 1999\end{array}$ & $\begin{array}{l}\text { In order to participate in the next General Election, } \\
\text { political parties must have as many as } 2 \% \text { (two-hun- } \\
\text { dredths) of the number of House of Representative } \\
\text { seats or have at least } 3 \% \text { (three-hundredths) of the } \\
\text { number of Regional House of Representative I or Re- } \\
\text { gional House of Representative II seats spread at least } \\
1 / 2 \text { (half) the number of provinces and in } 1 / 2 \text { (half) } \\
\text { the number of districts / municipalities throughout } \\
\text { Indonesia based on the results of the General Election. }\end{array}$ \\
\hline 2. & $\begin{array}{l}\text { Article } 9 \\
\text { paragraph (1) } \\
\text { of Law No. } \\
12 / 2003\end{array}$ & $\begin{array}{l}\text { In order to participate in the next Election, the Politi- } \\
\text { cal Parties of the Participants of the Election must: } \\
\text { a) gain at least } 3 \% \text { (three percent) of the House of } \\
\text { Representatives seats; } \\
\text { b) gain at least } 4 \% \text { (four percent) of the total seats of } \\
\text { the Provincial Parliament spread at least } 1 / 2 \text { (half) the } \\
\text { number of provinces throughout Indonesia; Or } \\
\text { c) gained at least } 4 \% \text { (four percent) of the number of } \\
\text { district/ city Regional House of Representative seats } \\
\text { spread across ó (half) the number of districts / cities } \\
\text { throughout Indonesia. }\end{array}$ \\
\hline 3. & $\begin{array}{l}\text { Article } 202 \text { law } \\
\text { No. } 10 \text { of } 2008\end{array}$ & $\begin{array}{l}\text { 1) Political Parties of Election Participants must meet } \\
\text { the voting threshold of at least } 2.5 \% \text { (two commas five } \\
\text { hundredths) of the number of valid votes nationally } \\
\text { to be included in the determination of the seat of the } \\
\text { House of Representatives. } \\
\text { 2) The provision stipulated in paragraph (1) does not } \\
\text { apply in the determination of the acquisition of seats } \\
\text { of the provincial parliament and the district/ city } \\
\text { parliament. }\end{array}$ \\
\hline 4. & $\begin{array}{l}\text { Article } 208 \\
\text { Law No. } \\
8 / 2012\end{array}$ & $\begin{array}{l}\text { Political parties must meet the voting threshold of at } \\
\text { least } 3.5 \text { percent (three commas five percent) of the } \\
\text { number of valid votes nationally to be included in the } \\
\text { determination of the seat of the Regional House of } \\
\text { Representative, provincial parliament, and district/ city } \\
\text { parliament. }\end{array}$ \\
\hline 5. & $\begin{array}{l}\text { Article } 414 \\
\text { paragraph (1) } \\
\text { of Law No. } 7 \\
\text { of } 2017\end{array}$ & $\begin{array}{l}\text { Political parties must meet the threshold of voting at least } \\
\text { four percent of the number of valid votes nationally to } \\
\text { be included in the determination of seats in the House } \\
\text { of Representatives. }\end{array}$ \\
\hline
\end{tabular}


wasted and do not get representation in the House of Representative.

Furthermore, not only about the size of the parliamentary threshold which increases in every election period, the function and purpose of this threshold are also being questioned by the public. As previously mentioned, the threshold was originally known as the electoral threshold. The electoral threshold aims to limit political parties in the context of their participation in the next election, not to limit the number of political parties in parliament based on the results of votes acquired in the election. Several parties have passed the phase and regulations regarding the electoral threshold, such as the PBB or Bulan Bintang Party (previously named Partai Bintang Bulan or Crescent and Moon Party) and PKS or Keadilan Sejahtera Party (previously named Partai Keadilan or Justice Party).

The electoral threshold is considered fairer because it only impacts on changing party names without having to seize party votes and seats in parliament. Thus, when the electoral threshold was changed to a parliamentary threshold, many practitioners and academics began to reject and provide their critical notes. Therefore, it is no surprise that the application of the electoral threshold or parliamentary threshold in the election raises pros and cons among the public, that impacts judicial review testing in the Constitutional Court.

It is learnt from the table 2 that there are 2 characters of the parliamentary threshold decided by the Constitutional Court, which is related to the nature of its constitutionality and its unconstitutionality. The Court's opinion broadly refers to the scope of the enactment of the parliamentary threshold, the object of which is the target of the parliamentary threshold as well as the guarantee of protection of human rights, especially the right to be elected in the contest of elections. Although often questioned in every election period, the parliamentary threshold remains in place today. The legal dynamics in the application of the parliamentary threshold, by Romli Atmasasmita, are commonly referred to by the term tripartite character of social and bureaucratic engineering or the combination of dynamic 
Table 2. Judicial Review of Parliamentary Thresholds

\begin{tabular}{|c|c|c|}
\hline No & $\begin{array}{l}\text { Constitutional Court } \\
\text { Decision }\end{array}$ & About \\
\hline 1. & $\begin{array}{l}\text { Constitutional Court } \\
\text { Decision Number } 16 / \\
\text { PUU-V/2007 }\end{array}$ & $\begin{array}{l}\text { The application of the parliamentary } \\
\text { threshold does not conflict with the } 1945 \\
\text { Constitution of the NRI }\end{array}$ \\
\hline 2. & $\begin{array}{l}\text { Constitutional Court } \\
\text { Decision Number } 3 \text { / PUU- } \\
\text { VII/ } 2009\end{array}$ & $\begin{array}{l}\text { The application of the parliamentary } \\
\text { threshold does not conflict with the } 1945 \\
\text { Constitution of the NRI }\end{array}$ \\
\hline 3. & $\begin{array}{l}\text { Constitutional Court } \\
\text { Decision Number 52/ } \\
\text { PUU-X/2012 }\end{array}$ & $\begin{array}{l}\text { The national parliamentary threshold was } \\
\text { cancelled and only applies to the House of } \\
\text { Representatives }\end{array}$ \\
\hline 4. & $\begin{array}{l}\text { Constitutional Court De- } \\
\text { cision Number 20/PUU- } \\
\text { XVI/2018 }\end{array}$ & $\begin{array}{l}\text { The application of the parliamentary } \\
\text { threshold does not conflict with the } 1945 \\
\text { Constitution of the NRI }\end{array}$ \\
\hline 5. & $\begin{array}{l}\text { Constitutional Court De- } \\
\text { cision Number } 48 \text { / PUU- } \\
\text { XVIII/ } 2020\end{array}$ & $\begin{array}{l}\text { Legal standing of the applicant is invalid, so } \\
\text { the Court does not check until the point of }\end{array}$ \\
\hline
\end{tabular}

norm systems, behavioral systems and value systems sourced in Pancasila. ${ }^{16}$

It is called a dynamic norm system because the provision of the parliamentary threshold and its application can be changed and become an open legal policy for lawmakers/legislators. ${ }^{17}$ The system of conduct appears in the application of parliamentary thresholds in reaction to the failure of a political party to pass a set parliamentary threshold. Meanwhile, Pancasila's value system came about when the Constitutional Court overturned the application of the national parliamentary threshold because it potentially violated political rights

16 Romli Atmasasmita, "Memahami Teori Hukum Integratif," Legalitas 3, no. 2 (2012): 1-13, http://legalitas.unbari.ac.id/index.php/Legalitas/article/ view/132/116.

17 Iwan Satriawan and Tanto Lailam, “Open Legal Policy Dalam Putusan Mahkamah Konstitusi Dan Pembentukan Undang-Undang,” Jurnal Konstitusi 16, no. 3 (2019): 559-84, http: / consrev.mkri.id/index.php/jk/article/ view/1636; Radita Ajie, "Batasan Pilihan Kebijakan Pembentuk UndangUndang (Open Legal Policy) Dalam Pembentukan Peraturan PerundangUndangan Berdasarkan Tafsir Putusan Mahkamah Konstitusi,” Jurnal Legislasi Indonesia (Indonesian Journal of Legislation) Vol. 13, no. No.2 Juni (2016): 111-20. 
at the legislative elections level of the DPRD (DPRD Province and DPRD City/Regency).

Efforts to make the law more beneficial to human life, dynamic and create harmony, have long been the noble ideals of Indonesian legal experts, as offered by Muchtar Kusumaatmadja in development law theory or Satjipto Rahardjo in progressive law theory. ${ }^{18}$ There is also a new idea from Romli Atmasasmita known as integrative legal theory, which tries to accommodate the idea of development laws and progressive laws. Nevertheless, integrative law has its own pattern and peculiarities, namely 1) the use of living law as an enforcement effort; and 2) resolve conflicts or legal issues with out-of-court pathways ${ }^{19}$ using such living laws. ${ }^{20}$ Integrative law wants bureaucratic engineering done through a system of norms and behaviors and community engineering done through a value system. ${ }^{21}$

Through integrative law, Romli Atmasasmita hopes that the law not only prints people (red. artisans) who are intelligent in law, ${ }^{22}$ but also builds a humanity (humanist law) that cares about the problems of legal uncertainty, injustice and social vulnerability in society. ${ }^{23} \mathrm{Hu}-$ manist law is a law that is human-oriented, provides protection on the basis of human dignity (principle of human dignity) and pays attention to the weak/vulnerable (principle of vulnerability), with the postulates: (1) upholding human dignity as the image of the creator;

18 Sayuti, "Arah Kebijakan Pembentukan Hukum ke Depan (Pendekatan Teori Hukum Pembangunan, Teori Hukum Progresif, dan Teori Hukum Integratif)," Ar-Risalah 13, no. 2 (2013): 1-22, https:// doi.org/https:// doi. org/10.30631/al-risalah.v13i02.407.

19 J. Kim Right, "Integrative Law," University of Western Australia Law Review 46, no. 2 (2019): 237-52, https: / / doi.org/10.5694/j.1326-5377.1960.tb78483.x.

20 Sayuti, op.cit.

21 Ibid.

22 Rhonda V Magee, "Legal Education as Contemplative Inquiry: An Integrative Approach to Legal Education, Law Practice, and the Substance of the Law We Make," The Journal of Contemplative Inquiry 3, no. 1 (2016): 7-20.

23 Romli Atmasasmita, "Tiga Paradigma Hukum," Jurnal Hukum Prioris 3, no. 1 (2012): 1-26; Unair News, "Teori Hukum Integratif Sebagai Kontribusi Pemikiran Evolusioner Di Indonesia," Unair, 2019, http://news.unair. ac.id/2019/06/12/teori-hukum-integratif-sebagai-kontribusi-pemikiranevolusioner-di-indonesia/. 
(2) conscientious rules to protect vulnerable people; (3) provide justice; and (4) responsive and anticipatory. ${ }^{24}$

Thus, if integrative law becomes one of the foundations for the Judges of the Constitution in breaking the case for reviewing the norms of parliamentary thresholds, it looks like the threshold of parliament will be decided to be abolished because it can not provide justice. Justice in the application of parliamentary thresholds is defined by the Constitutional Court as a reasonable contest in elections no one wins or loses. In fact, in the values derived from Pancasila, social justice for all Indonesians does not emphasize competition. Fairness is an absolute value that must be felt by the whole community without exception.

Therefore, in the human rights perspective, especially in the context of voting and voting rights, the application of parliamentary thresholds manifestly reduces such voting and voting rights. ${ }^{25}$ Many political parties, such as PBB, PKPI, Perindo, PSI, Garuda, Berkarya and so on that failed to meet the parliamentary threshold, so that the voters of the party could not be represented by the candidate they had chosen. Parties that fail to pass the parliamentary threshold, then their votes are contested into the remaining votes by parties that pass the parliamentary threshold. In real terms, it is part of the practice of human rights abuses. Unfortunately, these conditions are considered reasonable by the Constitutional Court on the grounds that every contestant must have won and some lost.

In the perspective of social vulnerability, noise due to the application of parliamentary thresholds is almost certain to occur in every election period. As mentioned earlier, during the implementation of elections that apply the norm of parliamentary thresholds, there is a judicial review effort. The judicial review effort has the potential

24 Supriyono Supriyono and Intan Kusumawati, "Revitalisasi Ideologi Pancasila Dalam Membentuk Konsep Hukum Yang Humanis," Academy of Education Journal 11, no. 01 (2020): 36-51, https:// doi.org/10.47200/aoej. v11i01.315. h. 50

25 Achmad Zakaria, "Pembatasan Partai Politik Peserta Pemilihan Umum Dalam Perspektif Demokrasiarya,” Jurnal Idea Hukum 2, no. 1 (2016): 1-11, https: / / doi.org/10.20884/1.jih.2016.2.1.24. 
to cause horizontal conflict and discontent among applicants, especially given the warning of a Constitutional Court decision that ruled in the case against the parliamentary threshold. It is very prone to conflict in the community. ${ }^{26}$ Thus, from an integrative legal perspective that looks at a legal norm from an un-myopic point of view, the application of parliamentary thresholds is irrelevant because it does not meet the element of justice and creates social vulnerability in society.

Nevertheless, the disciplinary background of Romli Atmasasmita, who is originally a Professor in Criminal Law, is quite strong in influencing his ideas regarding integrative law. The principle of legality, which underswers legal rigor and conflict resolution through the courts, seems to be a benchmark for integrative law enforcement. Both can be found in criminal law studies. So, the ideas and critical theories about integrative law introduced by Romli Atmasasmita have several weaknesses, such as: 1). His criminal law background is very strong in coloring the idea of integrative law, so that the idea of integrative law may not necessarily be suitable if adopted as a grand theory or flow/benchmark in legal development in Indonesia; 2). The idea of integrative law is like the idea of progressive law that founded by Satjipto Rahardjo. Thus, the notion of integrative law seems to be based on observing, replicating and modifying.

In another hand, ideas in integrative legal theory to resolve conflicts or legal disputes in court, assumptions as interesting and actual ideas. In fact, nowadays in the practice of state law for example, a conflict or legal matter may not be resolved through the courts. Alternatively, legal norms do not have to be rigidly changed through amendments to the law, but also through interpretations made by judges. ${ }^{27}$ What's more, in the conflict and dynamics of applying par-

26 Chastiti Mediafira Wulolo and Edward Semuel Renmaur, "Meredam Konflik dalam Pusaran Siber dalam Proses Penetapan Hasil Rekapitulasi Pemilu Serentak 2019," Jurnal Penelitian Politik (LIPI) 16, no. 1 (2019): 111-124, https: / / doi.org/https: / / doi.org/10.14203/jpp.v16i2.801.

27 Iskandar Muda, "Penafsiran Hukum Yang Membentuk Keadilan Legal Dalam Penyelesaian Sengketa Perbankan Syariah,” Jurnal Yudisial 9, no. 1 (2016): 37-50, https: / / doi.org/doi.org/10.29123/jy.v9i1.30. 
liamentary thresholds, bureaucratic engineering and social engineering seems to be quite difficult to do because of the polarization of interests.

Therefore, integrative legal theory hopes that Constitutional Judges can be more courageous in interpreting the definition, function and size of the threshold, not deciding that the parliamentary threshold is an open legal policy that made by legislators. The model of interpretation carried out by Constitutional Judges should also be able to explore the living law that exists in the community, for example in the practice of using Noken in Papua elections or Lunang in Baduy Dalam, Banten on election process. How are the values in the practices of Noken or Lunang, can accommodate the treasures of indigenous peoples in Papua and Baduy Dalam, resolve conflicts and make election results accepted by all levels of society.

Moreover, the above comprehensive discussion on the relationship of parliamentary thresholds in the perspective of integrative legal theory ultimately leads to the statement that the parliamentary threshold is not suitable to be applied in Indonesia. This is based on several factors: 1) The function and size of the parliamentary threshold deprives citizens of constitutional rights, especially in the context of political rights, namely to vote and be elected. Because political parties that fail to pass the parliamentary threshold will automatically have their votes wasted. 2) Disputes resulting from the pros and cons of implementing the parliamentary threshold still must be resolved in the Constitutional Court. In fact, from an integrative legal perspective, disputes should be resolved out of court; and 3) The application of the parliamentary threshold in Indonesia has not been able to accommodate the existing living law in the community. As is well known, the idea of a parliamentary threshold is a policy that is widely used abroad, especially in European countries with specific goals, such as: limiting the influence of communists/Nazis into parliament, perpetuating the power of major parties and so on. Thus, based on an integrative legal perspective, the parliamentary threshold, both in terms of function and size, is not appropriate to be applied in Indonesia. 


\section{Conclusion}

Based on the above discussion, it can be concluded that the application of parliamentary thresholds in elections based on an integrative legal perspective is not appropriate because it has not been able to guarantee the fulfillment of a sense of justice for all Indonesians. Nevertheless, the idea of integrative law based on the disciplinary practice of criminal law also opens up a space of weakness that legal academics must answer immediately. As a solution, it is necessary to propose a new idea of a legal concept formulated by some legal experts with a variety of different disciplines in order to be more comprehensive.

\section{Bibliography}

Al-Fatih, Sholahuddin. "Electoral Regulation in Indonesia : Is It Modern Law ?” Unnes Law Journal 6, no. 2 (2020): 205-16. https: / / doi.org/https: / / doi.org/10.15294/ulj.v6i2.41627.

------. "Akibat Hukum Regulasi Tentang Threshold DalamPemilihan Umum Legislatif Dan Pemilihan Presiden: Kajian Putusan Mahkamah Konstitusi Nomor 52/PUU-X/2012 Dan Nomor 14/ PUU-XI/2013.” Jurnal Yudisial 12, no. 1 (2019): 17-38. https:/ / doi.org/10.29123/jy.v12i1.258.

Atmasasmita, Romli. 2012. Teori Hukum Integratif: Rekonstruksi Terhadap Teori Hukum Pembangunan dan Teori Hukum Progresif; Yogyakarta: Genta Publshing

------. “Memahami Teori Hukum Integratif." Legalitas 3, no. 2 (2012): 1-13. http://legalitas.unbari.ac.id/index.php/Legalitas/article/view/132/116.

Fatih, Sholahuddin Al. "Implementasi Parliamentary Threshold Dalam Pemilihan Anggota Dprd Provinsi Dan Dprd Kabupaten/ Kota." Ahkam: Jurnal Hukum Islam 6, no. 2 (2018). https:// doi. org/10.21274/ahkam.2018.6.2.363-388.

- "Penerapan Threshold dalam Pemilu." Audito Comparative Law Journal 1, no. 2 (2020): 78-84. https: / / doi.org/ https:/ / doi. org/10.22219/audito.v1i2.13973. 
Kusuma-atmaja, Mochtar. 2006. Konsep-Konsep Hukum dalam Pembangun-an; edited by Otje Salman and Eddy Damian, Bandung: Pusat Studi Wawasan Nusantara, Hukum dan Pembangunan in cooperation with PT. Alumni

Lijphart, Arend. Patterns of Democracy, Government Forms \& Performance in Thirty-Six Countries. 2nd ed. Yale: Yale University Press, 2012.

Magee, Rhonda V. "Legal Education as Contemplative Inquiry: An Integrative Approach to Legal Education, Law Practice, and the Substance of the Law We Make.” The Journal of Contemplative Inquiry 3, no. 1 (2016): 7-20.

Mellaz, August. "Praktek Penerapan Keberlakuan 3,5 Persen Ambang Batas Parlemen Secara Nasional Undang-Undang Nomor 8 Tahun 2012 Tentang Pemilu.” Jakarta, 2012. http: / / www.spdindonesia.com/wp-content/uploads / 2016/04 / Ambang-BatasTanpa-Batas.pdf.

Muda, Iskandar. "Penafsiran Hukum Yang Membentuk Keadilan Legal Dalam Penyelesaian Sengketa Perbankan Syariah.” Jurnal Yudisial 9, no. 1 (2016): 37-50. https:// doi.org/doi.org/10.29123/ jy.v9i1.30.

News, Unair. “Teori Hukum Integratif Sebagai Kontribusi Pemikiran Evolusioner Di Indonesia.” Unair, 2019. http://news.unair. ac.id/2019/06/12/ teori-hukum-integratif-sebagai-kontribusipemikiran-evolusioner-di-indonesia/.

Peter Mahmud Marzuki. Penelitian Hukum: Edisi Revisi. Cetakan ke. Jakarta: Kencana, 2017. https:/ / books.google.co.id/books?id= CKZADwAAQBAJ\&printsec $=$ frontcover $\& \mathrm{dq}=$ Marzuki, + Pete $\mathrm{r}+$ Mahmud, $+(2014),+$ Penelitian + Hukum, + Cetakan + ke-9, + Ja karta:+Kencana + Media + Group. $\&$ hl $=\mathrm{id} \&$ sa $=$ X \&ved $=0$ ahUKE wiNlIjqlbTpAhXWWisKHWktCXAQ6AEIMjAB\#v=onepage \&q\&f=false.

- Penelitian Hukum. Jakarta: Kencana Prenada Media Group, 2014.

Radita Ajie. "Batasan Pilihan Kebijakan Pembentuk Undang-Undang (Open Legal Policy) Dalam Pembentukan Peraturan Perun- 
dang-Undangan Berdasarkan Tafsir Putusan Mahkamah Konstitusi." Jurnal Legislasi Indonesia (Indonesian Journal of Legislation) Vol. 13, no. No.2 Juni (2016): 111-20.

Right, J. Kim. "Integrative Law." University of Western Australia Law Review 46, no. 2 (2019): 237-52. https: / / doi.org/10.5694/j.13265377.1960.tb78483.x.

Romli Artasasmita. “Tiga Paradigma Hukum.” Jurnal Hukum Prioris 3, no. 1 (2012): 1-26.

Satriawan, Iwan, and Tanto Lailam. "Open Legal Policy Dalam Putusan Mahkamah Konstitusi Dan Pembentukan Undang-Undang." Jurnal Konstitusi 16, no. 3 (2019): 559-84. http:/ / consrev. $\mathrm{mkri.id/index.php/jk/article/view/1636.}$

Sayuti. "Arah Kebijakan Pembentukan Hukum ke Depan (Pendekatan Teori Hukum Pembangunan, Teori Hukum Progresif, dan Teori Hukum Integratif)." Ar-Risalah 13, no. 2 (2013): 1-22. https:// doi.org/https: / / doi.org/10.30631/al-risalah.v13i02.407.

Wulolo, Chastiti Mediafira, and Edward Semuel Renmaur. "Meredam Konflik dalam Pusaran Siber dalam Proses Penetapan Hasil Rekapitulasi Pemilu Serentak 2019.” Jurnal Penelitian Politik (LIPI) 16, no. 1 (2019): 111-124. https:// doi.org/https:// doi. org/10.14203/jpp.v16i2.801.

Zakaria, Achmad. "Pembatasan Partai Politik Peserta Pemilihan Umum Dalam Perspektif Demokrasiarya.”Jurnal Idea Hukum 2, no. 1 (2016): 1-11. https:// doi.org/10.20884/1.jih.2016.2.1.24. 